\title{
Excision repair cross-complementing group 2 upregulation is a potential predictive biomarker for oral squamous cell carcinoma recurrence
}

\author{
YEN-YUN WANG ${ }^{1-4^{*}}$, PEN-TZU FANG ${ }^{5^{*}}$, CHANG-WEI SU $^{1,4,6}$, YUK-KWAN CHEN $^{1,4,7,8}$, \\ JOH-JONG HUANG ${ }^{9}$, MING-YII HUANG ${ }^{4,5,10,11}$ and SHYNG-SHIOU F. YUAN ${ }^{2-4,12-15}$
}

\begin{abstract}
${ }^{1}$ School of Dentistry, College of Dental Medicine, Kaohsiung Medical University; ${ }^{2}$ Translational Research Center and
${ }^{3}$ Department of Medical Research, Kaohsiung Medical University Hospital; ${ }^{4}$ Center for Cancer Research, Kaohsiung Medical University; ${ }^{5}$ Department of Radiation Oncology, ${ }^{6}$ Division of Oral and Maxillofacial Surgery and

${ }^{7}$ Division of Oral Pathology and Maxillofacial Radiology, Kaohsiung Medical University Hospital;

${ }^{8}$ Oral and Maxillofacial Imaging Center, College of Dental Medicine, Kaohsiung Medical University;

${ }^{9}$ Department of Family Medicine, Kaohsiung Medical University Hospital; ${ }^{10}$ Department of Radiation Oncology,

Faculty of Medicine, College of Medicine; ${ }^{11}$ Center for Biomarkers and Biotech Drugs, Kaohsiung Medical University;

${ }^{12}$ Department of Obstetrics and Gynecology, Kaohsiung Medical University Hospital; ${ }^{13}$ Graduate Institute of Medicine, College of Medicine, Kaohsiung Medical University, Kaohsiung 807377; ${ }^{14}$ Department of Biological Science and Technology, College of Biological Science and Technology; ${ }^{15}$ Center For Intelligent Drug Systems and Smart Bio-devices,

National Chiao Tung University, Hsinchu 300093, Taiwan, R.O.C.
\end{abstract}

Received October 12, 2020; Accepted March 10, 2021

DOI: $10.3892 / \mathrm{ol} .2021 .12711$

\begin{abstract}
Oral cancer is the fourth most common type of cancer among males in Taiwan, and the prognosis for patients with advanced-stage oral squamous cell carcinoma (OSCC) remains poor. The present study investigated the prognostic value of three DNA repair genes, namely excision repair cross-complementing group 1 (ERCC1), ERCC2 and X-ray repair cross-complementing group 1 (XRCC1) in OSCC. The protein expression levels of XRCC1, ERCC1 and ERCC2 in oral cell lines were analyzed via western blotting and immunohistochemistry using samples from 98 patients with biopsy-proven OSCC, while the $\chi^{2}$ test was used to analyze the clinicopathological association. Kaplan-Meier estimates were used to determine the prognostic value of XRCC1, ERCC1 and
\end{abstract}

Correspondence to: Professor Ming-Yii Huang, Department of Radiation Oncology, Kaohsiung Medical University Hospital, 100 Tzyou 1st Road, Kaohsiung 807377, Taiwan, R.O.C.

E-mail:miyihu@gmail.com

Professor Shyng-Shiou F. Yuan, Translational Research Center, Kaohsiung Medical University Hospital, 100 Tzyou 1st Road, Kaohsiung 807377, Taiwan, R.O.C.

E-mail: yuanssf@ms33.hinet.net

*Contributed equally

Key words: excision repair cross-complementing group 1, excision repair cross-complementing group $2, \mathrm{X}$-ray repair cross-complementing group 1, DNA repair, oral squamous cell carcinoma
ERCC2 for overall survival, and the log-rank test was used to evaluate the significance of differences. Multivariate analysis revealed a positive association between ERCC2 expression and OSCC recurrence (19.64-fold; 95\% CI, 5.00-77.1; P<0.001). In addition, the high protein expression levels of XRCC1, ERCC1 and ERCC2 were associated with poor disease-free and overall survival rates. Therefore, the present study suggested that high ERCC2 expression may be a risk factor for OSCC recurrence.

\section{Introduction}

The oral cavity is the most prevalent area of malignancy in the head and neck region, with the GLOBOCAN 2020 data estimating the annual incidence and mortality as $\sim 377,713$ new cases and 177,757 deaths, respectively, for lip and oral cavity cancer, which is the fourth most common type of cancer among males in Taiwan (1-3). Squamous cell carcinoma constitutes the most commonly seen histological type in patients with oral cavity cancer (4). Radical surgery with or without adjuvant chemo-radiotherapy is part of the primary management for patients with oral squamous cell carcinoma (OSCC), and radical surgery has proven to be valuable in loco-regional disease control (5). Although 80-90\% of early OSCC cases are cured, the prognosis for patients with advanced-stage OSCC remains poor $(6,7)$. For patients who have undergone standard management, OSCC recurrence varies between 18 and $76 \%$, and recurrence has been identified as the major cause of poor survival rates (8-11). Previous studies have indicated that the median time to recurrence is 7.5 months after therapy, with $86 \%$ of recurrences occurring among 24 months (12-14). 
In Taiwan, cisplatin is the mainstay of chemotherapy for locally advanced oral cancer treatment. Its crucial cytotoxic activity is due to the formation of DNA adducts, which result in inter-strand and intra-strand cross-linking $(15,16)$. These DNA cross-links are identified and eliminated by the nucleotide excision repair (NER) pathway protecting the integrity of the genome $(17,18)$. Tumor resistance to this platinum complex seems to be multifactorial, with the NER pathway serving a crucial role (19). NER is a stepwise procedure of recognition, incision, excision, DNA synthesis and ligation, which is executed by a multienzyme complex $(20,21)$. Previous studies have investigated the association between gene expression and the effects of various chemotherapeutic agents in cancer (22-24), such as excision repair cross-complementing group 1 (ERCC1) being identified as a marker for resistance to cisplatin in non-small-cell lung cancer. Platinum resistance has been attributed to enhanced repair of DNA damage via the NER pathway, which consists of X-ray cross-complementing 1 (XRCC1), ERCC1 and ERCC2 (25-28).

Concurrent chemo-radiotherapy is regularly used for locally advanced oral cancer treatment. DNA single-strand breaks may take place directly from the damage to deoxyribose, or indirectly as the ordinary intermediates of DNA base excision repair (29). Since single-strand breaks are provoked by endogenous reactive molecules, such as reactive oxygen species, these injuries create a sustained threat to genetic integrity (29). In mammalian cells, the XRCC1 protein plays a leading part in the repair of single-strand breaks via its capability to interact with multiple enzymatic complexes of restoration (29). Hypersensitivity to oxidative stress, ionizing radiation and alkylating agents has been observed in cells lacking XRCC1 (29). A previous study has indicated that high expression of both XRCC1 and ERCC1 is significantly associated with radioresistant laryngeal carcinoma (30).

XRCC1, ERCC1 and ERCC2 are well-reported DNA repair proteins, implying their involvement in resistance to chemo-radiotherapy; however, to the best of our knowledge, no studies have explored the association of these NER pathway-associated proteins with recurrence and prognosis in patients with OSCC. Therefore, the current study hypothesized that high protein expression levels of XRCC1, ERCC1 and ERCC2 may lead to treatment resistance and recurrence or poor clinical outcomes in patients with OSCC.

\section{Materials and methods}

Cell culture. Human oral keratinocytes (HOK; ScienCell Research Laboratories, Inc.) were incubated with Oral Keratinocyte Medium (ScienCell Research Laboratories, Inc.) in plates pre-coated with $2 \mu \mathrm{g} / \mathrm{cm}^{2}$ poly-L-lysine. DOK oral precancerous cells were grown in DMEM supplemented with 10\% FBS (both Thermo Fisher Scientific, Inc.), penicillin (100 U/ml), streptomycin $(100 \mu \mathrm{g} / \mathrm{ml})$, glutamine $(2 \mathrm{mM})$ and hydrocortisone $(5 \mu \mathrm{g} / \mathrm{ml})$. Oral cancer SAS, OECM1, HSC-3 and Cal-27 cells were grown in Eagle's Minimum Essential Medium (Thermo Fisher Scientific, Inc.) with glutamine (2 mM) and FBS (10\%), while human malignant glioma U87MG cells (American Type Culture Collection; glioblastoma of unknown origin) were grown in DMEM supplemented with $10 \%$ FBS. All cells were incubated in $5 \% \mathrm{CO}_{2}$ at $37^{\circ} \mathrm{C}$.
Western blotting. Total cell lysates were extracted using RIPA buffer (Thermo Fisher Scientific, Inc.) and protein concentrations were detected using the BCA protein assay (Bio-Rad Laboratories, Inc.). Protein lysates (20 $\mu \mathrm{g} /$ lane) were separated via $10 \%$ SDS-PAGE and transferred to a PVDF membrane, which was then blocked for $1 \mathrm{~h}$ at room temperature with $5 \%$ non-fat milk in TBS-0.1\% Tween-20 (TBST). Subsequently, the membrane was incubated overnight at $4^{\circ} \mathrm{C}$ with primary antibodies including XRCC1 monoclonal antibody (1:1,000; cat. no. GTX83411; GeneTex, Inc.), ERCC1 monoclonal antibody (1:1,000; cat. no. GTX22356; GeneTex, Inc.), ERCC2 polyclonal antibody (1:1,000; cat. no. GTX105357; GeneTex, Inc.) and $\beta$-actin antibody (1:10,000; cat. no. GTX629630; GeneTex, Inc.). After washing three times with TBST for $10 \mathrm{~min}$, the membrane was incubated with HRP-conjugated secondary antibody (1:5,000; cat. no. GTX213110-01; GeneTex, Inc.) for $2 \mathrm{~h}$ at room temperature. The immunoblots were visualized using Chemiluminescence Reagent Plus (PerkinElmer, Inc.) and quantified using Image $\mathrm{Lab}^{\mathrm{TM}}$ software version 5.1 (Bio-Rad Laboratories, Inc.).

Oncomine $^{T M}$ platform. To study the mRNA expression levels of XRCC1, ERCC1 and ERCC2 in oral cancer and normal oral tissues, Oncomine ${ }^{\mathrm{TM}}$ [Estilo Head-Neck: XRCC1160033_s_at (31), Peng Head-Neck: XRCC13864445 (32), Cromer Head-Neck: ERCC11902_at (33), Ginos Head-Neck: ERCC1203720_s_at (34), Peng Head-Neck: ERCC13865378 (32), Peng Head-Neck: ERCC23865301 (32), Ginos Head-Neck: ERCC2213468_at (34), Cromer Head-Neck: ERCC241095_at (33)], an integrated cancer microarray database and web-based data-mining platform (35), was used.

Patients. Between September 2002 and December 2011, a total of 98 patients with OSCC (92 men and 6 women) were enrolled from the Department of Oral and Maxillofacial Surgery of Kaohsiung Medical University Hospital (Kaohsiung, Taiwan), with a median follow-up time of 40 months (range, 2.4-137.4 months). G*Power (version 3.1.9.4; https://ps-powerand-sample-size-calculation.software.informer.com/3.1/), a freely available windows application software, was used for sample size and power estimation, with $\alpha=0.05$ and estimated effect size $w=0.46$. A total of 98 patients were recruited in the present study to achieve sufficient power of $\geq 90 \%$. The current study was approved by the Institutional Review Board of Kaohsiung Medical University Hospital (approval no. 20140158) and patient informed consent was waived by the Institutional Review Board due to the retrospective nature of the study. OSCC pathology was determined by two pathologists independently, and the final diagnoses were made using clinical and histological data. Patients without previous history of any treatment for oral cancer were included. Patients who were $<18$ or $>80$ years old were excluded. Baseline characteristic data included patient age, sex, tumor location, grade, tumor size, lymph node metastases and tumor stage; additionally, substance use, such as alcohol consumption, betel nut chewing or cigarette smoking, and adjunct treatment details were recorded (Table I). The mean age of the study group was 51.4 years and the median age was 51 years (age range, 31-76 years). Clinical staging of the patients was determined using the TNM staging system according to the 1992 
criteria of the American Joint Committee on Cancer/Union for International Cancer Control (36). The primary tumor locations were buccal mucosa (77.6\%) and tongue (22.4\%). All of the patients received surgery as primary treatment, and some patients received adjuvant treatment, such as radiotherapy and chemotherapy. A total of 62 patients received adjuvant chemotherapy, with the chemotherapy regimen consisting of cisplatin or carboplatin with or without the addition of 5-fluorouracil or paclitaxel. A total of 45 patients received adjuvant intensity-modulated radiotherapy, and the scheduled doses were given once per day, 5 days per week. Postoperative patients received the planned course of adjuvant radiotherapy of 60-66 Gy in 2-Gy fractions to the post-operative high-risk region.

Survival endpoints and recurrence. Follow-up data was retrieved and updated from case records obtained from the medical records department until October 2014. Any patient not followed up within the last six months was contacted by phone to determine their current health status. Primary endpoints were disease-free survival (DFS) and overall survival (OS), with DFS being measured from the date of surgery to the date of locoregional recurrence, distant metastases or death from any cause, while OS was measured from the date of surgery to the date of death from any cause. Postoperative recurrence was defined as a lesion that exhibited postoperative regrowth at the same site after confirmation of healing of the surgical wounds.

Immunohistochemical (IHC) analysis. To determine the expression levels of XRCC1, ERCC1 and ERCC2 in OSCC tissues by IHC staining, the tissues were fixed in $10 \%$ neutral buffered formalin for $48 \mathrm{~h}$ at room temperature to prepare paraffin-embedded tumor tissue blocks for IHC sections (4-mm-thick). For the normal control, the oral mucosa tissue from a delinked patient with fibroma was used after Institutional Review Board approval (approval no. KMUH-IRB-20140158). Sections were deparaffinized and rehydrated following standard methods. Briefly, the sections were deparaffinized with xylene for $5 \mathrm{~min}$ for three times and rehydrated in graded ethanol (80-100\%) for $5 \mathrm{~min}$. A microwave antigen retrieval procedure was performed for $20 \mathrm{~min}$ in citrate buffer ( $\mathrm{pH} 6.0$ ), and $3 \%$ hydrogen peroxide was used to block non-specific peroxidase reactions at room temperature for $10 \mathrm{~min}$. After washing twice with TBS, non-specific blocking was performed with Protein Block (Novolink Polymer Detection System; Leica Microsystems, Inc.) for $5 \mathrm{~min}$ at room temperature and washed twice with TBS. Following washing with TBS, sections were incubated with the aforementioned XRCC1 monoclonal antibody (1:100), ERCC1 monoclonal antibody (1:200) and ERCC2 polyclonal antibody $(1: 100)$ at $4^{\circ} \mathrm{C}$ overnight. The sections were subsequently incubated with the Post Primary rabbit anti-mouse IgG antibody (Novolink Polymer Detection System; Leica Microsystems, Inc.) for $30 \mathrm{~min}$ at room temperature as secondary antibody application. The staining intensity of tumor tissues was determined as score 0 (negative), score 1 (weak), score 2 (moderate) and score 3 (strong) for antigens present in the cytoplasm and nucleus of cells using a light microscope (magnification, x200), determined separately by two independent pathologists.
Table I. Clinicopathological characteristics of 98 patients with oral squamous cell carcinoma.

\begin{tabular}{|c|c|}
\hline Characteristics & $\mathrm{N}(\%)$ \\
\hline \multicolumn{2}{|l|}{ Age, years } \\
\hline$<50$ & $47(48.0)$ \\
\hline$\geq 50$ & $51(52.0)$ \\
\hline \multicolumn{2}{|l|}{ Sex } \\
\hline Male & $92(93.9)$ \\
\hline Female & $6(6.1)$ \\
\hline \multicolumn{2}{|l|}{ Cigarette smoking } \\
\hline No & $11(11.1)$ \\
\hline Yes & 87 (88.9) \\
\hline \multicolumn{2}{|c|}{ Betel quid chewing } \\
\hline No & $30(30.6)$ \\
\hline Yes & $68(69.4)$ \\
\hline \multicolumn{2}{|c|}{ Alcohol consumption } \\
\hline No & $35(35.7)$ \\
\hline Yes & $63(34.3)$ \\
\hline \multicolumn{2}{|l|}{ Tumor location } \\
\hline Buccal mucosa & $76(77.6)$ \\
\hline Tongue & $22(22.4)$ \\
\hline \multicolumn{2}{|l|}{ Grade } \\
\hline Grade 0 & $86(87.8)$ \\
\hline Grade I+II+III & $12(12.2)$ \\
\hline \multicolumn{2}{|l|}{ Tumor size } \\
\hline $\mathrm{T} 1$ & $22(22.4)$ \\
\hline $\mathrm{T} 2$ & $30(30.6)$ \\
\hline $\mathrm{T} 3$ & $6(6.1)$ \\
\hline $\mathrm{T} 4$ & $40(40.8)$ \\
\hline
\end{tabular}

Lymph node metastases

NO

$50(51.0)$

$\mathrm{N} 1$

$30(30.6)$

$\mathrm{N} 2$

$18(18.4)$

Tumor stage

I

18 (18.4)

II

$17(17.3)$

18 (18.4)

45 (45.9)

IV

$53(54.1)$

45 (45.9)

$36(36.7)$

$62(63.3)$

No

Recurrence

No

22 (22.4)

Pre-CT/RT recurrence

47 (48.0)

Post-CT/RT recurrence

RT, radiotherapy; CT, chemotherapy. 
Statistical analysis. Statistical analyses were performed using SPSS 19.0 (IBM Corp.). Descriptive statistics were used and compared using independent t-test, $\chi^{2}$ test or Fisher's exact test. Survival analyses were evaluated using the Kaplan-Meier method with the log-rank test, while the Cox proportional-hazards model was used for multivariate analysis. Furthermore, hazard ratios (HRs) and 95\% CIs were calculated by multivariable Cox regression models and used to investigate the association between clinicopathological characteristics and survival. DFS was defined as the time after surgery during which the patient survived with no sign of recurrence. OS was defined as the time elapsed between surgery and death. All P-values were two-sided, with $\mathrm{P}<0.05$ considered to indicate a statistically significant difference.

\section{Results}

Expression profiles of XRCC1, ERCC1 and ERCC2 in oral cancer cell lines. Since DNA repair proteins are essential for oral cancer cells in response to chemo-radiotherapy, the expression levels of XRCC1, ERCC1 and ERCC2 in HOK normal oral epithelial cells, DOK oral pre-cancer cells and oral cancer SAS, OECM1, HSC-3 and Cal-27 cell lines were first examined using western blotting (Fig. 1), with U87MG glioblastoma cells being included as a positive control for XRCC1, ERCC1 and ERCC2 proteins (37). The results revealed that the expression levels of XRCC1 and ERCC1 were weakly detected in all oral cancer cells, while ERCC2 expression was detected in all cell lines (Fig. 1). Notably, HOK cells had lower ERCC2 protein expression compared with DOK cells and the oral cancer cell lines.

Association of XRCC1, ERCC1 and ERCC2 expression in OSCC tissues with clinicopathological characteristics. In the present study, 98 patients with OSCC (92 men and 6 women) were included. The clinicopathological characteristics of these patients, including age, sex, tumor location, grade, tumor size, lymph node metastases, tumor stage, radiotherapy, chemotherapy, smoking habit and recurrence, are shown in Table I. XRCC1, ERCC1 and ERCC2 expression in oral cancer tissues, as well as in normal oral mucosa tissue of a patient with fibroma, was analyzed using an online database and IHC analysis. The Oncomine database revealed that the mRNA expression levels of XRCC1, ERCC1 and ERCC2 were significantly increased in oral cancer tissues compared with in normal epithelial tissues (Fig. S1), except in the Peng Head-Neck XRCC1-3864445 dataset, where there was no significant difference, but there was still a trend toward XRCC1 elevation in oral cancer tissues ( $\mathrm{P}=0.061$; Fig. S1A). Notably, IHC staining without addition of the primary antibody was used as a negative control for XRCC1, ERCC1 and ERCC2 staining (Fig. S2). According to the staining intensity in tumor tissues, the expression levels of the three proteins were categorized into four scores (0-3). $\mathrm{XRCC} 1$ and ERCC1 proteins were predominantly stained in the nuclei, while ERCC2 protein was predominantly stained in the cytoplasm of oral cancer tissues (Fig. 2). To analyze the association between the protein expression levels of the three proteins in OSCC tissues and clinicopathological characteristics, the expression levels of the three proteins were further divided into high expression (score 3 ) and low expression (score 0-2) groups. High expression groups of XRCC1

\begin{tabular}{l} 
U87MG \\
\cline { 2 - 9 } XRCC1
\end{tabular}

Figure 1. XRCC1, ERCC1 and ERCC2 protein expression in primary oral epithelial cells, oral pre-cancer cells and various oral cancer cells. The cell lysates extracted from HOK primary oral epithelial cells, DOK oral pre-cancer cells and oral cancer cell lines, including SAS, OECM1, HSC-3 and Cal-27, underwent western blotting for detecting the expression levels of XRCC1, ERCC1 and ERCC2. Glioblastoma U87MG cell line served as a positive control. The numbers correspond to the grey density values of a single replicate. XRCC1, X-ray repair cross-complementing group 1; ERCC1/2, excision repair cross-complementing group 1/2.

$(\mathrm{P}=0.020)$, ERCC1 $(\mathrm{P}=0.006)$ or ERCC2 $(\mathrm{P}<0.001)$ were significantly associated with OSCC recurrence (Tables II-IV). Furthermore, univariate and multivariate analyses were used to explore OSCC recurrence predictors in patients with OSCC. In univariate analysis, lymph node metastases $(\mathrm{N} 1+\mathrm{N} 2)$, high $\mathrm{XRCC} 1$ expression, high ERCC1 expression and high ERCC2 expression were significantly associated with OSCC recurrence $(\mathrm{P}=0.006, \mathrm{P}=0.020, \mathrm{P}=0.006$ and $\mathrm{P}<0.001$, respectively; Table $\mathrm{V}$ ). In multivariate analysis, lymph node metastases $(\mathrm{N} 1+\mathrm{N} 2)$ (2.38-fold; 95\% CI, 1.02-5.58; $\mathrm{P}=0.045)$ and high ERCC2 expression (4.84-fold; 95\% CI, 2.56-9.16; $\mathrm{P}<0.001)$ were significantly associated with increased risk of OSCC recurrence (Table V).

Univariate and multivariate analyses were also used to explore OSCC survival predictors in patients with OSCC. In univariate analysis, tumor size, lymph node metastases (N1+N2), tumor stage, high XRCC1 expression, high ERCC1 expression and high ERCC2 expression were significantly associated with a worse survival in patients with OSCC $(\mathrm{P}=0.001, \mathrm{P}=0.005, \mathrm{P}=0.001, \mathrm{P}=0.002, \mathrm{P}=0.014$ and $\mathrm{P}<0.001$, respectively; Table VI). In multivariate analysis, tumor location (4.11-fold; 95\% CI, 1.392-12.14; $\mathrm{P}=0.01$ ) and high ERCC2 expression (15.55-fold; 95\% CI, 4.34-55.67; $\mathrm{P}<0.001)$ were significantly associated with increased risk of death (Table VI).

The association between the expression levels of the three proteins and DFS or OS rates in patients with OSCC was analyzed using the Kaplan-Meier method. Significantly decreased DFS rates were observed in patients with high expression levels of XRCC1, ERCC 1 and ERCC 2 ( $\mathrm{P}=0.020$, $\mathrm{P}=0.040$ and $\mathrm{P}<0.001$, respectively), as well as significantly decreased OS rates in patients with high expression levels of $\mathrm{XRCC} 1, \mathrm{ERCC} 1$ and ERCC2 $(\mathrm{P}=0.002, \mathrm{P}=0.014$ and $\mathrm{P}<0.001$, respectively), as determined using the log-rank test (Fig. 3). The findings of the survival analysis indicating that high ERCC2 expression indicated a poor prognosis were consistent with the results of the multivariate analysis.

\section{Discussion}

In the present study, the association between the expression levels of NER pathway-associated genes and the recurrence 

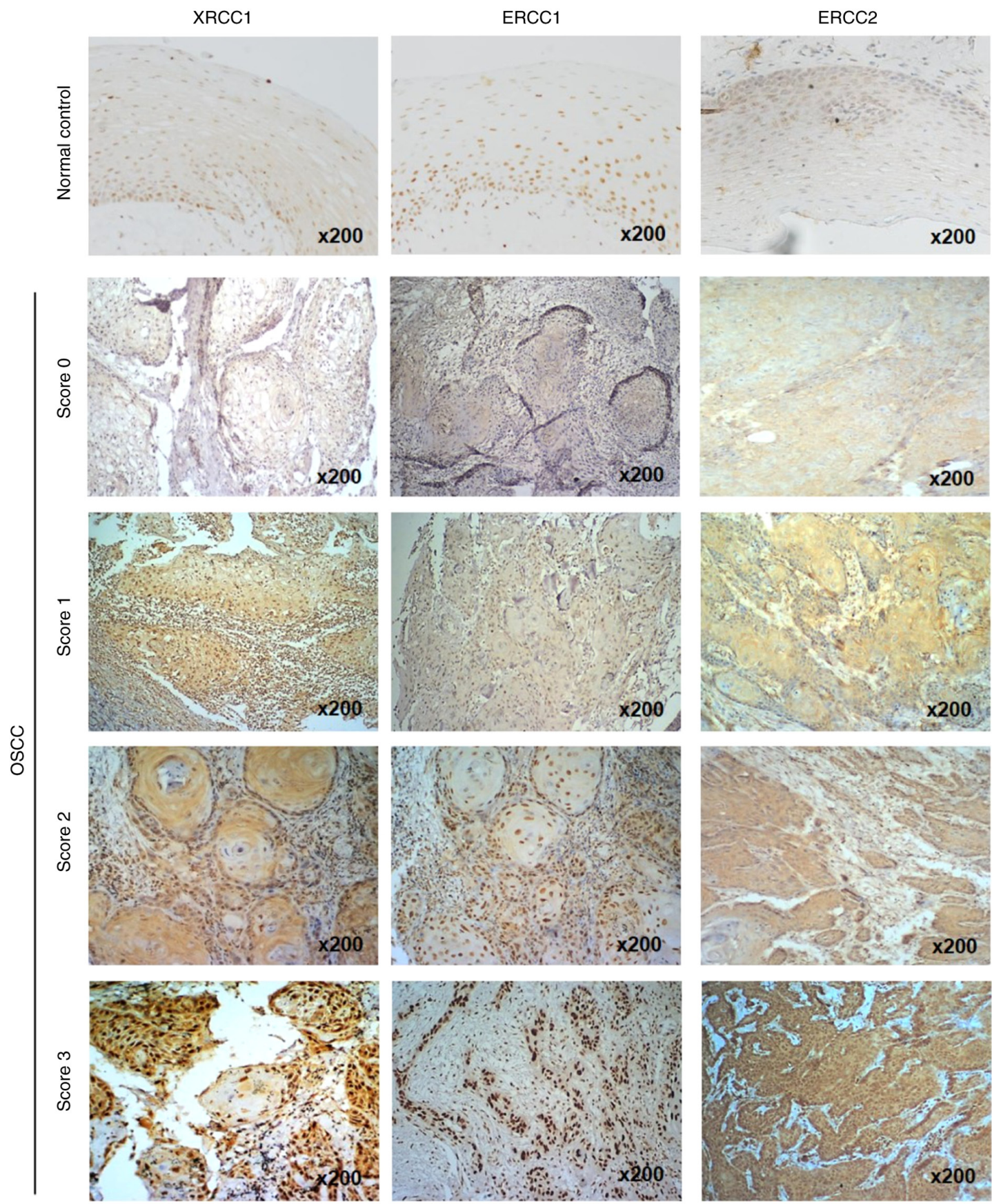

Figure 2. Immunohistochemical staining of XRCC1, ERCC1 and ERCC2 expression in OSCC tissues. ERCC1, ERCC2 or XRCC1 expression in oral normal tissues and cancer tissues, determined by immunohistochemistry, was divided into 4 categories according to the staining intensity: Score 0, no staining; score 1, weak staining; score 2, moderate staining; and score 3, strong staining. Original magnification, x200. XRCC1, X-ray repair cross-complementing group 1; ERCC1/2, excision repair cross-complementing group 1/2; OSCC, oral squamous cell carcinoma.

and survival outcome in patients with OSCC was explored by examining the expression levels of XRCC1, ERCC1 and ERCC2 in a series of oral cavity epithelial cells, revealing that ERCC2, but not ERCC1 or XRCC1, exhibited a trend of positive association with the neoplastic development from normal epithelium to dysplasia and OSCC. However, some cancer cells expressed lower expression levels of XRCC1, ERCC1 and ERCC2 than HOK normal oral keratinocytes and DOK oral precancerous cells, and this requires further investigation. In addition, high expression levels of the three proteins in OSCC tissues were significantly associated with worse OS and DFS rates compared with low expression levels.
Notably, the multivariate analysis revealed that high ERCC2 expression was an independent prognostic marker for OSCC recurrence.

High ERCC1 expression in head and neck squamous cell carcinoma (HNSCC) has been extensively studied as a potential prognostic biomarker for the chemoradiotherapy response and survival prognosis of patients with HNSCC (38-42). Although the genetic variations of ERCC2 and XRCC1 have been reported to be associated with increased risk and worse clinical outcome of oral cancer (43-47), there is very little data on ERCC2 and XRCC1 expression in oral cancer. A systematic review and case-control study has revealed 
Table II. Association between clinical characteristics of patients with oral squamous cell carcinoma and XRCC1 expression.

XRCC1 expression

\begin{tabular}{|c|c|c|c|}
\hline \multirow{2}{*}{ Characteristics } & & & \multirow[b]{2}{*}{ P-value } \\
\hline & Low, n (\%) & High, n (\%) & \\
\hline \multicolumn{4}{|l|}{ Age, years } \\
\hline$<50$ & $13(46.4)$ & $34(48.6)$ & \multirow[t]{2}{*}{0.850} \\
\hline$\geq 50$ & $15(53.6)$ & $36(51.4)$ & \\
\hline \multicolumn{4}{|l|}{ Sex } \\
\hline Male & $28(100.0)$ & $64(91.4)$ & \multirow[t]{2}{*}{$0.180^{\mathrm{a}}$} \\
\hline Female & $0(0.0)$ & $6(8.6)$ & \\
\hline \multicolumn{4}{|l|}{ Cigarette smoking } \\
\hline No & $1(3.6)$ & $10(14.3)$ & \multirow[t]{2}{*}{$0.170^{\mathrm{a}}$} \\
\hline Yes & $27(96.4)$ & $60(85.7)$ & \\
\hline \multicolumn{4}{|c|}{ Betel quid chewing } \\
\hline No & $7(25.0)$ & $23(32.9)$ & \multirow[t]{2}{*}{0.450} \\
\hline Yes & $21(75.0)$ & $47(37.1)$ & \\
\hline \multicolumn{4}{|c|}{ Alcohol consumption } \\
\hline No & $6(21.4)$ & $29(41.4)$ & \multirow[t]{2}{*}{0.070} \\
\hline Yes & $22(78.6)$ & $41(58.6)$ & \\
\hline \multicolumn{4}{|l|}{ Tumor location } \\
\hline Buccal mucosa & $24(85.7)$ & $52(74.3)$ & \multirow[t]{2}{*}{$0.290^{\mathrm{a}}$} \\
\hline Tongue & $4(14.3)$ & $18(25.7)$ & \\
\hline \multicolumn{4}{|l|}{ Grade } \\
\hline Grade I & $26(92.9)$ & $60(85.7)$ & \multirow[t]{2}{*}{$0.500^{\mathrm{a}}$} \\
\hline Grade II+III & $2(7.1)$ & $10(14.3)$ & \\
\hline \multicolumn{4}{|l|}{ Tumor size } \\
\hline $\mathrm{T} 1+\mathrm{T} 2$ & $16(57.1)$ & $36(51.4)$ & \multirow[t]{2}{*}{0.610} \\
\hline $\mathrm{T} 3+\mathrm{T} 4$ & $12(42.9)$ & $34(48.6)$ & \\
\hline \multicolumn{4}{|c|}{ Lymph node metastases } \\
\hline No & $15(53.6)$ & $35(50.0)$ & \multirow[t]{2}{*}{0.750} \\
\hline $\mathrm{N} 1+\mathrm{N} 2$ & $13(46.4)$ & $35(50.0)$ & \\
\hline \multicolumn{4}{|l|}{ Tumor stage } \\
\hline $\mathrm{I}+\mathrm{II}$ & $11(39.3)$ & $24(34.3)$ & \multirow[t]{2}{*}{0.640} \\
\hline $\mathrm{III+IV}$ & $17(60.7)$ & $46(65.7)$ & \\
\hline \multicolumn{4}{|l|}{ Radiotherapy } \\
\hline No & $18(64.3)$ & $35(50.0)$ & \multirow[t]{2}{*}{0.200} \\
\hline Yes & $10(35.7)$ & $35(50.0)$ & \\
\hline \multicolumn{4}{|l|}{ Chemotherapy } \\
\hline No & $12(42.9)$ & $24(34.3)$ & \multirow[t]{2}{*}{0.430} \\
\hline Yes & $16(57.1)$ & $46(65.7)$ & \\
\hline Recurrence & & & \\
\hline No & $13(46.4)$ & $16(22.9)$ & 0.020 \\
\hline Yes & $15(53.6)$ & $54(77.1)$ & \\
\hline
\end{tabular}

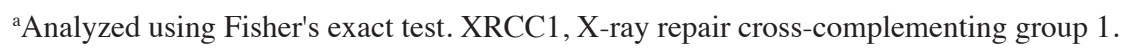

that ERCC2 expression is significantly increased in HNSCC tissues compared with in adjacent normal tissues, and that it is positively associated with tumor stage and grade (48). The present study indicated that ERCC1, ERCC2 and XRCC1 expression was associated with the survival rate of patients with OSCC. To the best of our knowledge, the current study is the first to suggest ERCC2 as a prognostic marker for OSCC recurrence.

The association between the synthesis of DNA repair proteins in tumor cells and the patient response to 
Table III. Association between clinical characteristics of patients with oral squamous cell carcinoma and ERCC1 expression.

ERCC1 expression

\begin{tabular}{|c|c|c|c|}
\hline \multirow{2}{*}{ Characteristics } & & & \multirow[b]{2}{*}{ P-value } \\
\hline & Low, n (\%) & High, n (\%) & \\
\hline \multicolumn{4}{|l|}{ Age, years } \\
\hline$<50$ & $19(47.5)$ & $28(48.3)$ & \multirow[t]{2}{*}{0.940} \\
\hline$\geq 50$ & $21(52.5)$ & $30(51.7)$ & \\
\hline \multicolumn{4}{|l|}{ Sex } \\
\hline Male & $36(90.0)$ & 56 (96.6) & \multirow[t]{2}{*}{$0.220^{\mathrm{a}}$} \\
\hline Female & $4(10.0)$ & $2(3.4)$ & \\
\hline \multicolumn{4}{|l|}{ Smoking } \\
\hline No & $4(10.0)$ & $7(12.1)$ & \multirow[t]{2}{*}{$>0.999^{\mathrm{a}}$} \\
\hline Yes & $36(90.0)$ & $51(87.9)$ & \\
\hline \multicolumn{4}{|c|}{ Betel quid chewing } \\
\hline No & $11(27.5)$ & $19(32.8)$ & \multirow[t]{2}{*}{0.580} \\
\hline Yes & $29(72.5)$ & $39(67.2)$ & \\
\hline \multicolumn{4}{|c|}{ Alcohol consumption } \\
\hline No & $14(35.0)$ & $21(36.2)$ & \multirow[t]{2}{*}{0.900} \\
\hline Yes & $26(65.0)$ & $37(63.8)$ & \\
\hline \multicolumn{4}{|l|}{ Tumor location } \\
\hline Buccal mucosa & $32(80.0)$ & $44(75.9)$ & \multirow[t]{2}{*}{0.630} \\
\hline Tongue & $8(20.0)$ & $14(24.1)$ & \\
\hline \multicolumn{4}{|l|}{ Grade } \\
\hline Grade I & $35(87.5)$ & $51(87.9)$ & \multirow[t]{2}{*}{$>0.999$} \\
\hline Grade II+III & $5(12.5)$ & $7(12.1)$ & \\
\hline \multicolumn{4}{|l|}{ Tumor size } \\
\hline $\mathrm{T} 1+\mathrm{T} 2$ & $22(55.0)$ & $30(51.7)$ & \multirow[t]{2}{*}{0.750} \\
\hline $\mathrm{T} 3+\mathrm{T} 4$ & $18(45.0)$ & $28(48.3)$ & \\
\hline \multicolumn{4}{|c|}{ Lymph node metastases } \\
\hline No & $22(55.0)$ & $28(48.3)$ & \multirow[t]{2}{*}{0.510} \\
\hline $\mathrm{N} 1+\mathrm{N} 2$ & $18(45.0)$ & $30(51.7$ & \\
\hline \multicolumn{4}{|l|}{ Tumor stage } \\
\hline $\mathrm{I}+\mathrm{II}$ & $15(37.5)$ & $20(34.5)$ & \multirow[t]{2}{*}{0.760} \\
\hline $\mathrm{III+IV}$ & $25(62.5)$ & $38(65.5)$ & \\
\hline \multicolumn{4}{|l|}{ Radiotherapy } \\
\hline No & $23(57.5)$ & $30(51.7)$ & \multirow[t]{2}{*}{0.680} \\
\hline Yes & $17(42.5)$ & $28(48.3)$ & \\
\hline \multicolumn{4}{|l|}{ Chemotherapy } \\
\hline No & $17(42.5)$ & $19(32.8)$ & \multirow[t]{2}{*}{0.330} \\
\hline Yes & $23(57.5)$ & $39(67.2)$ & \\
\hline Recurrence & & & \\
\hline No & $18(45.0)$ & $11(19.0)$ & 0.006 \\
\hline Yes & $22(55.0)$ & $47(81.0)$ & \\
\hline
\end{tabular}

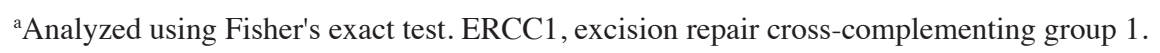

chemo-radiotherapy has been reported in different types of cancer. In patients with non-small cell lung cancer, low ERCC1 expression indicates an improved prognosis after treatment with multidrug chemotherapy (22). High XRCC1 and ERCC1 expression is associated with a poor prognosis in patients with HER2 ${ }^{+}$breast cancer (47), while high ERCC1 expression has been associated with resistance to platinum-based chemotherapy in patients with ovarian cancer (49). In addition, ectopic ERCC1 expression in ovarian cancer cells increases the resistance to cisplatin-mediated growth inhibition (50). 
Table IV. Association between clinical characteristics of patients with oral squamous cell carcinoma and ERCC2 expression.

ERCC2 expression

\begin{tabular}{|c|c|c|c|}
\hline \multirow{2}{*}{ Characteristics } & & \multirow[b]{2}{*}{ P-value } \\
\hline & Low, n (\%) & High, n (\%) & \\
\hline \multicolumn{4}{|l|}{ Age, years } \\
\hline$<50$ & $21(53.8)$ & $26(44.1)$ & \multirow[t]{2}{*}{0.340} \\
\hline$\geq 50$ & $18(46.2)$ & $33(55.9)$ & \\
\hline \multicolumn{4}{|l|}{$\operatorname{Sex}$} \\
\hline Male & $36(92.3)$ & 56 (94.9) & \multirow[t]{2}{*}{$0.680^{\mathrm{a}}$} \\
\hline Female & $3(7.7)$ & $3(5.1)$ & \\
\hline \multicolumn{4}{|l|}{ Smoking } \\
\hline No & $5(12.8)$ & $6(10.2)$ & \multirow[t]{2}{*}{0.680} \\
\hline Yes & $34(87.2)$ & $53(89.8)$ & \\
\hline \multicolumn{4}{|c|}{ Betel quid chewing } \\
\hline No & $8(20.5)$ & $22(37.3)$ & \multirow[t]{2}{*}{0.080} \\
\hline Yes & $31(79.5)$ & $37(62.7)$ & \\
\hline \multicolumn{4}{|c|}{ Alcohol consumption } \\
\hline No & $12(30.8)$ & $23(39.0)$ & \multirow[t]{2}{*}{0.410} \\
\hline Yes & $27(39.2)$ & $36(61.0)$ & \\
\hline \multicolumn{4}{|l|}{ Tumor location } \\
\hline Buccal mucosa & $28(71.8)$ & $48(81.4)$ & \multirow[t]{2}{*}{0.270} \\
\hline Tongue & $11(28.2)$ & $11(18.6)$ & \\
\hline \multicolumn{4}{|l|}{ Grade } \\
\hline Grade I & $34(87.2)$ & $52(88.1)$ & \multirow[t]{2}{*}{$>0.999$} \\
\hline Grade II+III & $5(12.8)$ & 7 (11.9) & \\
\hline \multicolumn{4}{|l|}{ Tumor size } \\
\hline $\mathrm{T} 1+\mathrm{T} 2$ & $24(61.5)$ & $28(47.5)$ & \multirow[t]{2}{*}{0.170} \\
\hline $\mathrm{T} 3+\mathrm{T} 4$ & $15(38.5)$ & $31(52.5)$ & \\
\hline \multicolumn{4}{|c|}{ Lymph node metastases } \\
\hline No & $24(61.5)$ & $26(44.1)$ & \multirow[t]{2}{*}{0.090} \\
\hline $\mathrm{N} 1+\mathrm{N} 2$ & $15(38.5)$ & $33(55.9)$ & \\
\hline \multicolumn{4}{|l|}{ Tumor stage } \\
\hline $\mathrm{I}+\mathrm{II}$ & $18(46.2)$ & $17(28.8)$ & \multirow[t]{2}{*}{0.080} \\
\hline $\mathrm{III+IV}$ & $21(53.8)$ & $42(71.2)$ & \\
\hline \multicolumn{4}{|l|}{ Radiotherapy } \\
\hline No & $20(51.3)$ & $33(55.9)$ & \multirow[t]{2}{*}{0.650} \\
\hline Yes & $19(48.7)$ & $26(44.1)$ & \\
\hline \multicolumn{4}{|l|}{ Chemotherapy } \\
\hline No & $18(46.2)$ & $18(30.5)$ & \multirow[t]{2}{*}{0.120} \\
\hline Yes & $21(53.8)$ & $41(69.5)$ & \\
\hline Recurrence & & & \\
\hline No & $23(59.0)$ & $6(10.2)$ & $<0.001$ \\
\hline Yes & $16(41.0)$ & $53(89.8)$ & \\
\hline
\end{tabular}

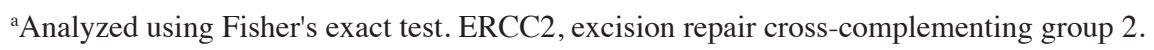

NER capacity serves a major role in normal tissue tolerance and drug resistance; moreover, ERCC2 and ERCC1 act as rate-limiting enzymes in NER (51). During NER, ERCC2 participates in DNA unwinding, and this function may alter the platinum-based chemotherapy effect (52). In a previous study, the genotypes of XRCC1 rs1799782 and XRCC2 rs2040639 DNA repair genes were significantly associated with oral cancer in Taiwan (44). Several studies have suggested that cancer cells with upregulation of DNA repair proteins are more resistant to chemoradiotherapy (53-55). Therefore, according to the present study, further investigation on the mechanism of the biological process of ERCC2 may provide 
Table V. Univariate and multivariate analyses of recurrence predictors in 98 patients with oral squamous cell carcinoma.

\begin{tabular}{|c|c|c|c|c|c|}
\hline \multirow[b]{2}{*}{ Characteristics } & \multicolumn{2}{|c|}{ Recurrence } & \multirow{2}{*}{$\frac{\text { Univariate analysis }}{\text { P-value }}$} & \multicolumn{2}{|c|}{ Multivariate analysis } \\
\hline & Yes & No & & Hazard ratio $(95 \% \mathrm{CI})$ & P-value \\
\hline \multicolumn{6}{|l|}{ Age, years } \\
\hline$\geq 50$ & $32(46.4)$ & $19(65.5)$ & 0.080 & 1.0 & 0.370 \\
\hline$<50$ & $37(53.6)$ & $10(34.5)$ & & $1.28(0.75-2.20)$ & \\
\hline \multicolumn{6}{|l|}{ Sex } \\
\hline Female & $3(4.3)$ & $3(10.3)$ & 0.360 & 1.0 & 0.290 \\
\hline Male & $66(95.7)$ & $26(89.7)$ & & $0.48(0.13-1.83)$ & \\
\hline \multicolumn{6}{|l|}{ Smoking } \\
\hline No & $8(11.6)$ & $3(10.3)$ & $>0.999$ & 1.0 & 0.400 \\
\hline Yes & $61(88.4)$ & $26(89.1)$ & & $0.64(0.22-1.84)$ & \\
\hline \multicolumn{6}{|c|}{ Betel quid chewing } \\
\hline No & $23(33.3)$ & $7(24.1)$ & 0.370 & 1.0 & 0.330 \\
\hline Yes & $46(66.7)$ & $22(75.9)$ & & $1.39(0.72-2.71)$ & \\
\hline \multicolumn{6}{|c|}{ Alcohol consumption } \\
\hline No & $27(39.1)$ & $8(27.6)$ & 0.370 & 1.0 & 0.960 \\
\hline Yes & $42(60.9)$ & $21(72.4)$ & & $0.98(0.54-1.81)$ & \\
\hline \multicolumn{6}{|l|}{ Tumor location } \\
\hline Buccal mucosa & $53(76.8)$ & $23(79.3)$ & 0.790 & 1.0 & 0.190 \\
\hline Tongue & $16(23.2)$ & $6(20.7)$ & & $0.64(0.32-1.25)$ & \\
\hline \multicolumn{6}{|l|}{ Grade } \\
\hline Grade I & $60(87.0)$ & $26(89.7)$ & $>0.999$ & 1.0 & 0.680 \\
\hline Grade II+III & $9(13.0)$ & $3(10.3)$ & & $0.86(0.40-1.81)$ & \\
\hline \multicolumn{6}{|l|}{ Tumor size } \\
\hline $\mathrm{T} 1+\mathrm{T} 2$ & $34(49.3)$ & $18(62.1)$ & 0.250 & 1.0 & 0.150 \\
\hline $\mathrm{T} 3+\mathrm{T} 4$ & $35(50.7)$ & $11(37.9)$ & & $1.78(0.81-3.88)$ & \\
\hline \multicolumn{6}{|c|}{ Lymph node metastases } \\
\hline N0 & $29(42)$ & $21(72.4)$ & 0.006 & 1.0 & 0.045 \\
\hline $\mathrm{N} 1+\mathrm{N} 2$ & $40(58)$ & 8 (27.6) & & $2.38(1.02-5.58)$ & \\
\hline \multicolumn{6}{|l|}{ Tumor stage } \\
\hline $\mathrm{I}+\mathrm{II}$ & $21(30.4)$ & $14(48.3)$ & 0.090 & 1.0 & 0.460 \\
\hline III+IV & $48(69.6)$ & $15(51.7)$ & & $0.65(0.20-1.71)$ & \\
\hline \multicolumn{6}{|c|}{ XRCC1 expression } \\
\hline Low & $15(21.7)$ & $13(44.8)$ & 0.020 & 1.0 & 0.450 \\
\hline High & $54(78.3)$ & $16(55.2)$ & & $1.31(0.65-2.66)$ & \\
\hline \multicolumn{6}{|c|}{ ERCC1 expression } \\
\hline Low & $22(31.9)$ & $18(62.1)$ & 0.006 & 1.0 & 0.460 \\
\hline High & $47(68.1)$ & $11(37.9)$ & & $1.25(0.69-2.25)$ & \\
\hline \multicolumn{6}{|c|}{ ERCC2 expression } \\
\hline Low & $16(23.2)$ & $23(79.3)$ & $<0.001$ & 1.0 & $<0.001$ \\
\hline High & $53(76.8)$ & $6(20.7)$ & & $4.84(2.56-9.16)$ & \\
\hline
\end{tabular}

XRCC1, X-ray repair cross-complementing group 1; ERCC1/2, excision repair cross-complementing group 1/2.

potential targets for pharmacological modulation that helps improve the efficiency of chemo-radiotherapy.

Cigarette smoking, alcohol consumption and betel quid chewing are well-known risk factors for oral cancer. Most oral cancer cases $(\sim 90 \%)$ in South-East Asia are associated with smoking (56), while the proportions of cases associated with alcohol drinking and betel quid chewing are 80 and $75 \%$, respectively. These agents may act synergistically. A working group of the International Agency for Research on Cancer concluded that there was adequate evidence of an association between chewing betel quid together with tobacco use (chewing or smoking) as a combined risk factor (57). In areas 
Table VI. Univariate and multivariate analysis of survival predictors in 98 patients with oral squamous cell carcinoma.

\begin{tabular}{|c|c|c|c|c|c|}
\hline \multirow[b]{2}{*}{ Characteristics } & \multicolumn{2}{|c|}{ Death } & \multirow{2}{*}{$\frac{\text { Univariate analysis }}{\text { P-value }}$} & \multicolumn{2}{|c|}{ Multivariate analysis } \\
\hline & Yes & No & & Hazard ratio $(95 \% \mathrm{CI})$ & P-value \\
\hline \multicolumn{6}{|l|}{ Age, years } \\
\hline$\geq 50$ & $25(54.3)$ & $26(50.0)$ & 0.540 & $0.96(0.48-19.2)$ & 0.910 \\
\hline$<50$ & $21(45.7)$ & $26(50.0)$ & & 1 & \\
\hline \multicolumn{6}{|l|}{ Sex } \\
\hline Female & $3(6.5)$ & $3(5.8)$ & 0.410 & 1 & 0.290 \\
\hline Male & $43(93.5)$ & $49(94.2)$ & & $0.43(0.09-2.04)$ & \\
\hline \multicolumn{6}{|l|}{ Smoking } \\
\hline No & $5(10.9)$ & $6(11.5)$ & 0.880 & 1 & 0.350 \\
\hline Yes & $41(89.1)$ & $46(88.5)$ & & $0.53(0.14-2.00)$ & \\
\hline \multicolumn{6}{|c|}{ Betel quid chewing } \\
\hline No & $19(41.3)$ & $15(28.8)$ & 0.270 & 1 & 0.790 \\
\hline Yes & $27(58.7)$ & $37(71.2)$ & & $1.11(0.53-2.32)$ & \\
\hline \multicolumn{6}{|c|}{ Alcohol consumption } \\
\hline No & $17(37.0)$ & $18(34.6)$ & 0.910 & 1 & 0.460 \\
\hline Yes & $29(63.0)$ & $34(65.4)$ & & $1.33(0.62-2.86)$ & \\
\hline \multicolumn{6}{|l|}{ Tumor location } \\
\hline Buccal mucosa & $39(84.8)$ & $37(71.2)$ & 0.060 & 1 & 0.010 \\
\hline Tongue & $7(15.2)$ & $15(28.8)$ & & $4.11(1.39-12.14)$ & \\
\hline \multicolumn{6}{|l|}{ Grade } \\
\hline Grade I & $38(82.6)$ & $48(92.3)$ & 0.710 & 1 & 0.430 \\
\hline Grade II+III & $8(17.4)$ & $4(7.7)$ & & $0.71(0.30-1.67)$ & \\
\hline \multicolumn{6}{|l|}{ Tumor size } \\
\hline $\mathrm{T} 1+\mathrm{T} 2$ & $17(37.0)$ & $35(37.3)$ & 0.001 & 1 & 0.430 \\
\hline $\mathrm{T} 3+\mathrm{T} 4$ & $29(63.0)$ & $17(32.7)$ & & $1.55(0.52-4.58)$ & \\
\hline \multicolumn{6}{|c|}{ Lymph node metastases } \\
\hline N0 & $29(63.0)$ & $19(36.5)$ & 0.005 & 1 & 0.560 \\
\hline $\mathrm{N} 1+\mathrm{N} 2$ & $17(37.0)$ & $33(63.5)$ & & $1.31(0.54-31.8)$ & \\
\hline \multicolumn{6}{|l|}{ Tumor stage } \\
\hline $\mathrm{I}+\mathrm{II}$ & $9(19.6)$ & $26(50.0)$ & 0.001 & 1 & 0.500 \\
\hline III+IV & $37(80.4)$ & $26(50.0)$ & & $1.70(0.36-8.04)$ & \\
\hline \multicolumn{6}{|c|}{ XRCC1 expression } \\
\hline Low & $5(10.9)$ & $23(44.2)$ & 0.002 & 1 & 0.100 \\
\hline High & $41(89.1)$ & $29(41.4)$ & & $2.65(0.82-8.52)$ & \\
\hline \multicolumn{6}{|c|}{ ERCC1 expression } \\
\hline Low & $10(21.7)$ & $30(57.7)$ & 0.014 & 1 & 0.900 \\
\hline High & $36(78.3)$ & $22(42.3)$ & & $1.06(0.45-2.50)$ & \\
\hline \multicolumn{6}{|c|}{ ERCC2 expression } \\
\hline Low & $3(6.5)$ & $36(69.2)$ & $<0.001$ & 1 & $<0.001$ \\
\hline High & $43(93.5)$ & $16(60.2)$ & & $15.55(4.34-55.67)$ & \\
\hline
\end{tabular}

XRCC1, X-ray repair cross-complementing group 1; ERCC1/2, excision repair cross-complementing group 1/2.

where the habit of betel quid chewing is widespread, these risk factors should be taken into consideration and require further investigation. However, the influence of smoking on clinical outcome of patients with oral cancer is in debate, since while smoking has a negative impact on survival, its effect is influenced by other confounding factors, such as treatment method, age, tumor size, smoking status or dose-response relationship (58-62). When patients stop smoking, survival benefits have been observed in several types of cancer, including head and neck cancer $(59,63)$. In the current study, cigarette smoking, alcohol consumption and betel quid chewing were not associated with recurrence in univariate or multivariate 

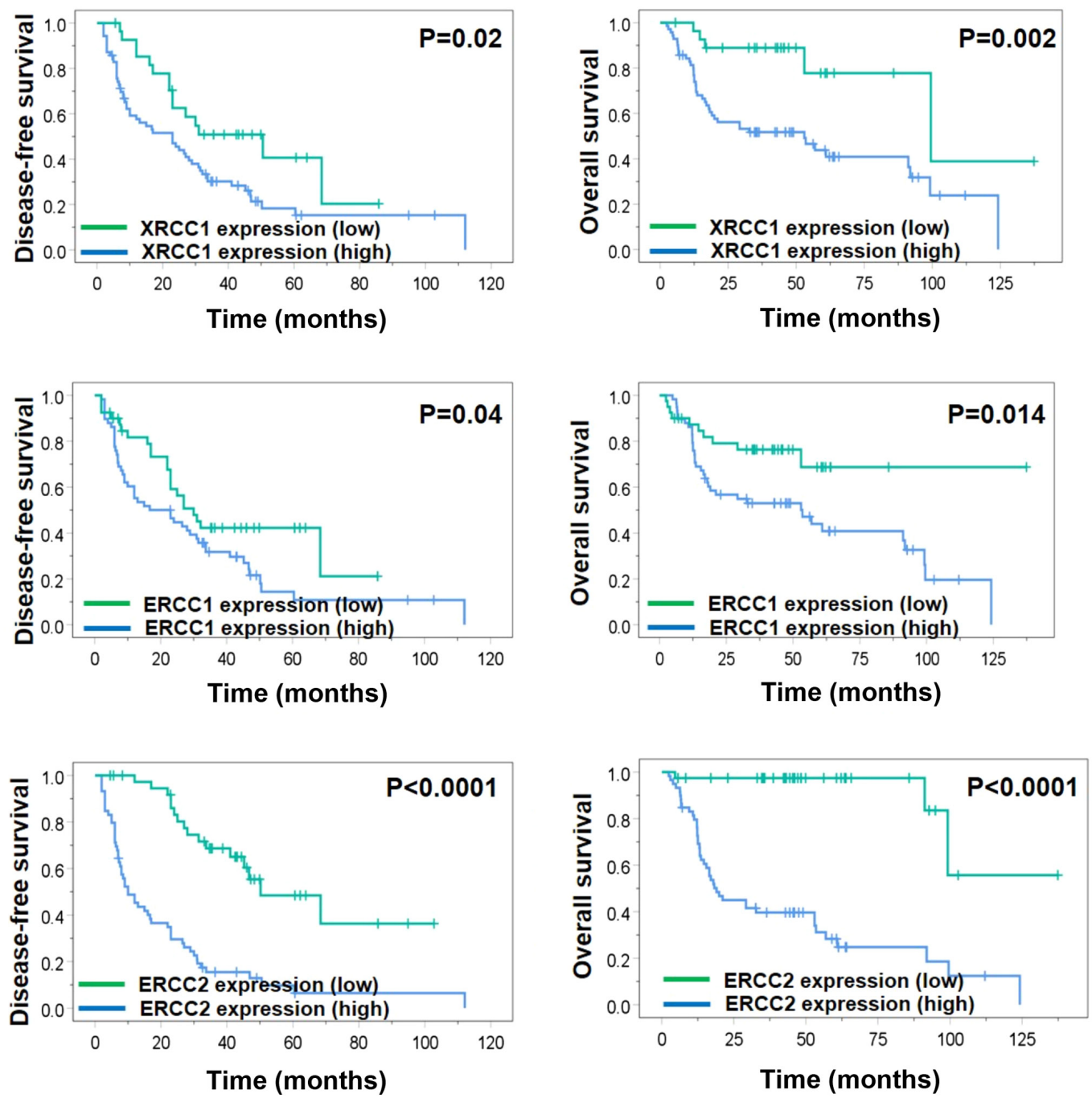

Figure 3. Disease-free survival and overall survival rates of patients with oral squamous cell carcinoma divided in low and high XRCC1, ERCC1 and ERCC2 expression groups. Survival curves were generated using the Kaplan-Meier method and the P-values were calculated using the log-rank test. XRCC1, X-ray repair cross-complementing group 1; ERCC1/2, excision repair cross-complementing group 1/2.

analysis, which may be due to fewer non-users. Further larger scale studies are required to solve this contradiction.

According to GLOBOCAN 2020, the ratio of oral cancer incidence in male and female is 2:1 in Asia and 2.5:1 worldwide; however, male is the predominant sex for oral cancer in Taiwan (2). According to the Taiwan cancer registry annual report 2017, the proportion of female patients with oral cancer was $10.7 \%$, and females represented $6 \%$ of the total sample size in the present study, which is similar to the general oral cancer population in Taiwan (3).

The current study has some limitations. First, data regarding socioeconomic factors were not collected and analyzed, and second, data were from a single tertiary cancer care center; therefore, more extensive multi-center studies are required to reinforce the present findings. Third, the median follow-up time was 40 months, and a longer follow-up time is required for full surveillance of cancer recurrence. Lastly, reverse transcription-quantitative PCR may also be a useful approach to analyze mRNA expression.

In future studies, the mechanisms of ERCC1, ERCC2 and $\mathrm{XRCC1}$ participating in OSCC carcinogenesis through the NER pathway should be analyzed both in vitro and in vivo, and larger prospective studies to validate the possible role of ERCC2 in OSCC outcome prediction should be performed.

\section{Acknowledgements}

Not applicable.

\section{Funding}

The present study was financially supported by grants from the Ministry of Health and Welfare of Taiwan (grant no. MOHW109-TDU-B-212-134016, Health and Welfare Surcharge of Tobacco Products) and from the 'Center For Intelligent Drug Systems and Smart Bio-devices' from The Featured Areas Research Center Program within the framework of the Higher Education Sprout Project by the Ministry of Education in Taiwan (grant no. IDS2B). Additionally, it was supported by grants from the Kaohsiung Medical University Hospital (grant nos. KMUH105-5R32, KMUH106-6R41, KMUH106-6R83, KMUH107-7R36, KMUH108-8R42, KMUH108-8R66,KMUH-DK109001-3 and KMUH109-9R78), Kaohsiung Medical University (Research Center Grant; grant 
nos. KMU-DK108005 and KMU-DK109001), Kaohsiung Medical University Research Center Grant (Center for Cancer Research; grant nos. KMU-TC108A04-0 and KMU-TC108A04-1) and the Ministry of Science and Technology of Taiwan (grant nos. MOST 107-2314-B-037-097-MY2,MOST 108-2314-B-037-021-MY3 and MOST 108-2314-B-037-014).

\section{Availability of data and materials}

The datasets used and/or analyzed during the current study are available from the corresponding author on request.

\section{Authors' contributions}

YYW, PTF, CWS, YKC, JJH, MYH and SSFY conceived and designed the experiments. YYW, YKC, MYH and SSFY performed the experiments. YYW, PTF, JYH, MYH and SSFY analyzed and discussed the data. YYW, PTF, MYH and SSFY contributed to reagents/materials/analysis tools. YYW, PTF, JYH, YKC, JJH, MYH and SSFY wrote the manuscript. MYH and SSFY are responsible for confirming the authenticity of the raw data. All authors read and approved the final manuscript.

\section{Ethics approval and consent to participate}

Ethics approval was obtained from the Institutional Review Board of Kaohsiung Medical University Hospital (approval no. 20140158) and informed consent was waived due to the retrospective nature of the study.

\section{Patient consent for publication}

Not applicable.

\section{Competing interests}

The authors declare that they have no competing interests.

\section{References}

1. Hsieh TY, Chang KP, Lee SS, Chang $\mathrm{CH}$, Lai $\mathrm{CH}, \mathrm{Wu} \mathrm{YC}$, Huang SH, Lai CS and Lin SD: Free flap reconstruction in patients with advanced oral squamous cell carcinoma: Analysis of patient survival and cancer recurrence. Microsurgery 32: 598-604, 2012.

2. Sung H, Ferlay J, Siegel RL, Laversanne M, Soerjomataram I, Jemal A and Bray F: Global cancer statistics 2020: GLOBOCAN estimates of incidence and mortality worldwide for 36 cancers in 185 countries. CA Cancer J Clin: Feb 4, 2021 (Epub ahead of print).

3. Ministry of Health Welfare: The cause of death in Taiwan in 2018. Available from: https://www.hpa.gov.tw/Pages/Detail. aspx?nodeid $=269 \&$ pid $=13498$.

4. Rivera $\mathrm{C}$ and Venegas B: Histological and molecular aspects of oral squamous cell carcinoma (Review). Oncol Lett 8: 7-11, 2014.

5. Liao CT, Wang HM, Ng SH, Yen TC, Lee LY, Hsueh C, Wei FC, Chen IH, Kang CJ, Huang SF and Chang JT: Good tumor control and survivals of squamous cell carcinoma of buccal mucosa treated with radical surgery with or without neck dissection in Taiwan. Oral Oncol 42: 800-809, 2006.

6. Eich HT, Löschcke M, Scheer M, Kocher M, Bongartz R, Wacker S, Zöller JE and Müller RP: Neoadjuvant radiochemotherapy and radical resection for advanced squamous cell carcinoma of the oral cavity. Outcome of 134 patients. Strahlenther Onkol 184: 23-29, 2008.
7. Kreppel M,Drebber U,Eich HT, Dreiseidler T,Zöller JE, Müller RP and Scheer M: Combined-modality treatment in advanced oral squamous cell carcinoma: Primary surgery followed by adjuvant concomitant radiochemotherapy. Strahlenther Onkol 187: 555-560, 2011.

8. Fan KH, Wang HM, Kang CJ, Lee LY, Huang SF, Lin CY, Chen EY, Chen IH, Liao CT and Chang JT: Treatment results of postoperative radiotherapy on squamous cell carcinoma of the oral cavity: Coexistence of multiple minor risk factors results in higher recurrence rates. Int J Radiat Oncol Biol Phys 77: 1024-1029, 2010

9. Woolgar JA, Rogers S, West CR, Errington RD, Brown JS and Vaughan ED: Survival and patterns of recurrence in 200 oral cancer patients treated by radical surgery and neck dissection. Oral Oncol 35: 257-265, 1999.

10. Liu CH, Chen HJ, Wang PC, Chen HS and Chang YL: Patterns of recurrence and second primary tumors in oral squamous cell carcinoma treated with surgery alone. Kaohsiung J Med Sci 29: 554-559, 2013.

11. Wang B, Zhang S, Yue K and Wang XD: The recurrence and survival of oral squamous cell carcinoma: A report of 275 cases. Chin J Cancer 32: 614-618, 2013.

12. Bernier J, Domenge C, Ozsahin M, Matuszewska K, Lefèbvre JL, Greiner RH, Giralt J, Maingon P, Rolland F, Bolla M, et al: Postoperative irradiation with or without concomitant chemotherapy for locally advanced head and neck cancer. N Engl J Med 350: 1945-1952, 2004.

13. Cooper JS, Pajak TF, Forastiere AA, Jacobs J, Campbell BH, Saxman SB, Kish JA, Kim HE, Cmelak AJ, Rotman M, et al: Postoperative concurrent radiotherapy and chemotherapy for high-risk squamous-cell carcinoma of the head and neck. N Engl J Med 350: 1937-1944, 2004.

14. Fan S, Tang QL, Lin YJ, Chen WL, Li JS, Huang ZQ, Yang ZH, Wang YY, Zhang DM, Wang HJ, et al: A review of clinical and histological parameters associated with contralateral neck metastases in oral squamous cell carcinoma. Int J Oral Sci 3: 180-191, 2011.

15. Pignon JP, le Maître A, Maillard E and Bourhis J; MACH-NC Collaborative Group: Meta-analysis of chemotherapy in head and neck cancer (MACH-NC): An update on 93 randomised trials and 17,346 patients. Radiother Oncol 92: 4-14, 2009.

16. Winquist E, Agbassi C, Meyers BM, Yoo J and Chan KKW; Head and Neck Disease Site Group: Systemic therapy in the curative treatment of head and neck squamous cell cancer: A systematic review. J Otolaryngol Head Neck Surg 46: 29, 2017.

17. Dabholkar M, Vionnet J, Bostick-Bruton F, Yu JJ and Reed E: Messenger RNA levels of XPAC and ERCC1 in ovarian cancer tissue correlate with response to platinum-based chemotherapy. J Clin Invest 94: 703-708, 1994.

18. Murray D and Rosenberg E: The importance of the ERCC1/ERCC4[XPF] complex for hypoxic-cell radioresistance does not appear to derive from its participation in the nucleotide excision repair pathway. Mutat Res 364: 217-226, 1996.

19. Manic S, Gatti L, Carenini N, Fumagalli G, Zunino F and Perego P: Mechanisms controlling sensitivity to platinum complexes: Role of p53 and DNA mismatch repair. Curr Cancer Drug Targets 3: 21-29, 2003.

20. Sancar A: DNA excision repair. Annu Rev Biochem 65: 43-81, 1996.

21. Petit $C$ and Sancar A: Nucleotide excision repair: From E. coli to man. Biochimie 81: 15-25, 1999.

22. Olaussen KA, Dunant A, Fouret P, Brambilla E, André F, Haddad V, Taranchon E, Filipits M, Pirker R, Popper HH, et al: DNA repair by ERCC1 in non-small-cell lung cancer and cisplatin-based adjuvant chemotherapy. N Engl J Med 355: 983-991, 2006.

23. Felip E and Rosell R: Testing for excision repair crosscomplementing 1 in patients with non-small-cell lung cancer for chemotherapy response. Expert Rev Mol Diagn 7: 261-268, 2007.

24. Olaussen KA, Mountzios G and Soria JC: ERCC1 as a risk stratifier in platinum-based chemotherapy for nonsmall-cell lung cancer. Curr Opin Pulm Med 13: 284-289, 2007.

25. Altaha R, Liang X, Yu JJ and Reed E: Excision repair cross complementing-group 1: Gene expression and platinum resistance. Int J Mol Med 14: 959-970, 2004.

26. Weaver DA, Crawford EL, Warner KA, Elkhairi F, Khuder SA and Willey JC: ABCC5, ERCC2, XPA and XRCC1 transcript abundance levels correlate with cisplatin chemoresistance in non-small cell lung cancer cell lines. Mol Cancer 4: 18, 2005 . 
27. Huang MY, Tsai HL, Lin CH, Huang CW, Ma CJ, Huang CM, Chai CY and Wang JY: Predictive value of ERCC1, ERCC2, and XRCC1 overexpression for stage III colorectal cancer patients receiving FOLFOX-4 adjuvant chemotherapy. J Surg Oncol 108: 457-464, 2013

28. Chiu TJ, Chen CH, Chien CY, Li SH, Tsai HT and Chen YJ: High ERCC1 expression predicts cisplatin-based chemotherapy resistance and poor outcome in unresectable squamous cel carcinoma of head and neck in a betel-chewing area. J Transl Med 9: 31, 2011.

29. Caldecott KW: XRCC1 and DNA strand break repair. DNA Repair (Amst) 2: 955-969, 2003.

30. Nix P, Greenman J, Stafford N and Cawkwell L: Expression of XRCC 1 and ERCC 1 proteins in radioresistant and radiosensitive laryngeal cancer. Cancer Ther 2: 47-53, 2004.

31. Estilo CL, O-charoenrat P, Talbot S, Socci ND, Carlson DL, Ghossein R, Williams T, Yonekawa Y, Ramanathan Y, Boyle JO, et al: Oral tongue cancer gene expression profiling: Identification of novel potential prognosticators by oligonucleotide microarray analysis. BMC Cancer 9: 11, 2009

32. Peng CH, Liao CT, Peng SC, Chen YJ, Cheng AJ, Juang JL, Tsai CY, Chen TC, Chuang YJ, Tang CY, et al: A novel molecular signature identified by systems genetics approach predicts prognosis in oral squamous cell carcinoma. PLoS One 6: e23452, 2011.

33. Cromer A, Carles A, Millon R, Ganguli G, Chalmel F, Lemaire F, Young J, Dembélé D, Thibault C, Muller D, et al: Identification of genes associated with tumorigenesis and metastatic potential of hypopharyngeal cancer by microarray analysis. Oncogene 23 : 2484-2498, 2004.

34. Ginos MA, Page GP, Michalowicz BS, Patel KJ, Volker SE, Pambuccian SE, Ondrey FG, Adams GL and Gaffney PM: Identification of a gene expression signature associated with recurrent disease in squamous cell carcinoma of the head and neck. Cancer Res 64: 55-63, 2004

35. Rhodes DR, Yu J, Shanker K, Deshpande N, Varambally R, Ghosh D, Barrette T,Pandey A and Chinnaiyan AM: ONCOMINE: A cancer microarray database and integrated data-mining platform. Neoplasia 6: 1-6, 2004

36. Verschuur HP, Irish JC, O'Sullivan B, Goh C, Gullane PJ and Pintilie M: A matched control study of treatment outcome in young patients with squamous cell carcinoma of the head and neck. Laryngoscope 109: 249-258, 1999.

37. Boccard SG, Marand SV, Geraci S, Pycroft L, Berger FR and Pelletier LA: Inhibition of DNA-repair genes Erccl and Mgmt enhances temozolomide efficacy in gliomas treatment: A pre-clinical study. Oncotarget 6: 29456-29468, 2015.

38. Huang PY, Li Y, Mai HQ, Luo RZ, Cai YC and Zhang L: Expression of ERCC1 predicts clinical outcome in locoregionally advanced nasopharyngeal carcinoma treated with cisplatin-based induction chemotherapy. Oral Oncol 48: 964-968, 2012.

39. Gao Y and Liu D: The roles of excision repair cross-complementation groupl in objective response after cisplatin-based concurrent chemoradiotherapy and survival in head and neck cancers: A systematic review and meta-analysis. Oral Oncol 51: 570-577, 2015

40. Bauman JE, Austin MC, Schmidt R, Kurland BF, Vaezi A, Hayes DN, Mendez E, Parvathaneni U, Chai X, Sampath S and Martins RG: ERCC1 is a prognostic biomarker in locally advanced head and neck cancer: Results from a randomised, phase II trial. Br J Cancer 109: 2096-2105, 2013.

41. An HJ, Jo H, Jung CK, Kang JH, Kim MS, Sun DI, Cho KJ, Cho JH, Won HS, Sun S and Ko YH: Prognostic implication of ERCC1 protein expression in resected oropharynx and oral cavity cancer. Pathol Res Pract 213: 949-955, 2017.

42. Yang L, Wei W, Zhou L, Wang J and Hu G: High/positive expression of ERCC1 predicts poor treatment response and survival prognosis in nasopharyngeal carcinoma: A systematic meta-analysis from 21 studies. Medicine (Baltimore) 98: e15641, 2019.

43. Zhang Y, Wang Y, Wu J and Li LJ: XRCC1 Arg194Trp polymorphism is associated with oral cancer risk: Evidence from a meta-analysis. Tumour Biol 34: 2321-2327, 2013.

44. Yang CH, Lin YD, Yen CY, Chuang LY and Chang HW: A systematic gene-gene and gene-environment interaction analysis of DNA repair genes XRCC1, XRCC2, XRCC3, XRCC4, and oral cancer risk. Omics 19: 238-247, 2015.
45. Avci H, Ergen A, Bireller ES, Ertugrul B and Cakmakoglu B: A strong relationship between oral squamous cell carcinoma and DNA repair genes. Biochem Genet 55: 378-386, 2017.

46. Zhang E, Cui Z, Xu Z, Duan W, Huang S, Tan X, Yin Z, Sun C and Lu L: Association between polymorphisms in ERCC2 gene and oral cancer risk: Evidence from a meta-analysis. BMC Cancer 13: 594, 2013.

47. Vaezi A, Feldman $\mathrm{CH}$ and Niedernhofer LJ: ERCC1 and XRCC1 as biomarkers for lung and head and neck cancer. Pharmgenomics Pers Med 4: 47-63, 2011.

48. Zafeer M, Mahjabeen I and Kayani MA: Increased expression of ERCC2 gene in head and neck cancer is associated with aggressive tumors: A systematic review and case-control study. Int J Biol Markers 31: e17-e25, 2016.

49. Du P, Wang Y, Chen L, Gan Y and Wu Q: High ERCC1 expression is associated with platinum-resistance, but not survival in patients with epithelial ovarian cancer. Oncol Lett 12: 857-862, 2016.

50. Liu J, Zhang L, Mao P, Jiang G, Liu L, Wang J, Yang W, Owusu L and Li W: Functional characterization of a novel transcript of ERCC1 in chemotherapy resistance of ovarian cancer. Oncotarget 8: 85759-85771,2017.

51. Gossage L and Madhusudan S: Current status of excision repair cross complementing-group 1 (ERCC1) in cancer. Cancer Treat Rev 33: 565-577, 2007.

52. Lai JI, Tzeng CH, Chen PM, Lin JK, Lin TC, Chen WS, Jiang JK, Wang HS and Wang WS: Very low prevalence of XPD K751Q polymorphism and its association with XPD expression and outcomes of FOLFOX-4 treatment in Asian patients with colorectal carcinoma. Cancer Sci 100: 1261-1266, 2009.

53. Curtin NJ: DNA repair dysregulation from cancer driver to therapeutic target. Nat Rev Cancer 12: 801-817, 2012.

54. Schulz A, Meyer F, Dubrovska A and Borgmann K: Cancer stem cells and radioresistance: DNA repair and beyond. Cancers (Basel) 11: 862, 2019.

55. Huang RX and Zhou PK: DNA damage response signaling pathways and targets for radiotherapy sensitization in cancer. Signal Transduct Target Ther 5: 60, 2020.

56. Johnson N: Tobacco use and oral cancer: A global perspective. J Dent Educ 65: 328-339, 2001

57. Ko YC, Huang YL, Lee CH, Chen MJ, Lin LM and Tsai CC: Betel quid chewing, cigarette smoking and alcohol consumption related to oral cancer in Taiwan. J Oral Pathol Med 24: 450-453, 1995.

58. Abrahão R, Anantharaman D, Gaborieau V, Abedi-Ardekani B, Lagiou P, Lagiou A, Ahrens W, Holcatova I, Betka J, Merletti F, et al: The influence of smoking, age and stage at diagnosis on the survival after larynx, hypopharynx and oral cavity cancers in Europe: The ARCAGE study. Int J Cancer 143: 32-44, 2018.

59. Cao W, Liu Z, Gokavarapu S, Chen Y, Yang R and Ji T: Reformed smokers have survival benefits after head and neck cancer. Br J Oral Maxillofac Surg 54: 818-825, 2016.

60. Colares N, Souza Rodrigues DF, Freitas MO, Dantas TS, Cunha MDPSS, Sousa FB and Barros Silva PG: Smoking history decreases survival in patients with squamous cell carcinoma of the mouth: A retrospective study with 15 years of follow-up. Asian Pac J Cancer Prev 20: 1781-1787, 2019.

61. Kawakita D, Hosono S, Ito H, Oze I, Watanabe M, Hanai N, Hasegawa Y, Tajima K, Murakami S, Tanaka H and Matsuo K: Impact of smoking status on clinical outcome in oral cavity cancer patients. Oral Oncol 48: 186-191, 2012.

62. Lee SU, Moon SH, Choi SW, Cho KH, Park JY, Jung YS, Ryu J, Ryu CH, Yun T, Kim TH, et al: Prognostic significance of smoking and alcohol history in young age oral cavity cancer. Oral Dis 26: 1440-1448, 2020.

63. Koshiaris C, Aveyard P, Oke J, Ryan R, Szatkowski L, Stevens R and Farley A: Smoking cessation and survival in lung, upper aero-digestive tract and bladder cancer: Cohort study. Br J Cancer 117: 1224-1232, 2017.

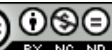

This work is licensed under a Creative Commons Attribution-NonCommercial-NoDerivatives 4.0 International (CC BY-NC-ND 4.0) License. 